\title{
Erratum to: Bacterial Pathogen Helicobacter pylori: A Bad AKTor Inhibits p53 Protein Activity
}

\author{
Alexander I. Zaika
}

Published online: 10 February 2015

(c) Springer Science+Business Media New York 2015

\section{Erratum to: Dig Dis Sci}

DOI 10.1007/s10620-014-3511-x

The original version of this article unfortunately contained an error in the article title. A word space erroneously introduced between "AKT" and "or" in "AKTor" during the production process. The corrected title should be Bacterial Pathogen Helicobacter pylori: A Bad AKTor Inhibits p53 Protein Activity.

The online version of the original article can be found under doi:10.1007/s10620-014-3511-x.

A. I. Zaika ( ()

Department of Surgery, Vanderbilt-Ingram Cancer Center,

Vanderbilt University, Nashville, TN, USA

e-mail: alex.zaika@vanderbilt.edu

A. I. Zaika

Department of Cancer Biology, Vanderbilt-Ingram Cancer

Center, Vanderbilt University, Nashville, TN, USA

\section{A. I. Zaika}

Department of Veterans Affairs, Tennessee Valley Healthcare

System, Nashville, TN, USA 